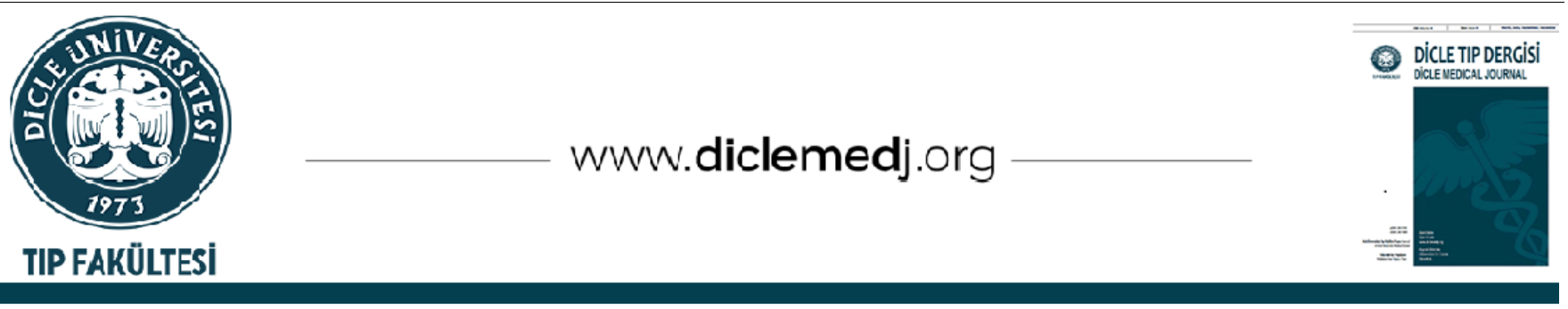

Case Report / Olgu Sunumu

\title{
A Rare Cause of Piyogenic Liver Abscess: Gemella morbillorum
}

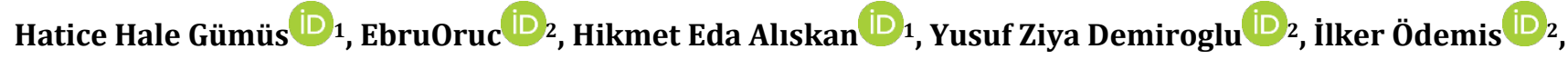 \\ Zafer Koc iD $_{3}$ \\ 1 Baskent University Faculty of Medicine, Adana Dr Turgut Noyan Practice and Research Hospital, Department of Medical Microbiology, Adana, Turkey \\ 2 Baskent University Faculty of Medicine, Adana Dr Turgut Noyan Practice and Research Hospital, Department of Infectious Diseases and Clinical \\ Microbiology, Adana, Turkey \\ 3 Baskent University Faculty of Medicine, Adana Dr Turgut Noyan Practice and Research Hospital, Department of Radiology, Adana, Turkey
}

Received: 10.09.2021; Revised: 14.11.2021; Accepted: 22.11.2021

\begin{abstract}
We report a rare case of Gemella morbillorum associated pyogenic liver abscess in an immunocompetent 57-year-old female patient in this document. Gemella morbillorum is a gram-positive cocci found in the upper respiratory, genitourinary and gastrointestinal system microbiota. The bacterium is a member of the genus Gemella, and rare causative agent of endocarditis, brain abscess and bacteremia as an opportunistic pathogen. To the best of our knowledge,we present the first case of G. morbillorum associated pyogenic liver abscess in Turkey. The pathophysiology, diagnostic method and treatment of liver abscesses vary depending on the etiology. G. morbillorum is rare, but should be kept in the back of the mind while treating a patient with pyogenic liver abscess.
\end{abstract}

Keywords: Pyogenic liver abscess, Gram-positive coccus, Gemella morbillorum, Betametazon dipropiyonat, Percutaneous drainage.

\section{Piyojenik Karaciğer Apsesinin Nadir bir Etkeni: Gemella morbillorum}

\section{Öz}

Bu çalışmada, immun sistem defekti olmayan 57 yaşında bir kadın hastada Gemella morbillorum ile ilişkili piyojenik karaciğer apsesi olan nadir bir vakayı sunuyoruz. Gemella morbillorum, üst solunum yolu, genitoüriner ve gastrointestinal sistem mikrobiyotasında bulunan gram pozitif bir koktur. Bakteri Gemella cinsinin bir üyesidir ve firsatçı bir patojen olarak endokardit, beyin apsesi ve bakteriyeminin nadir bir etkenidir. Bildiğimiz kadarıyla, Türkiye'deki ilk G. morbillorum ilişkili piyojenik karaciğer apsesi olgusunu sunuyoruz. Karaciğer apselerinin patofizyolojisi, tanı yöntemi ve tedavisi etiyolojiye göre değişir. G. morbillorum nadirdir, ancak piyojenik karaciğer apsesi olan bir hastayı tedavi ederken akılda tutulmalıdır.

Anahtar kelimeler: Piyojenik karaciğer apsesi, Gram pozitif kok, Gemella morbillorum, Betametazon dipropiyonat, Perkütan drenaj.

DOI: 10.5798/dicletip.1037917

Correspondence / Yazışma Adresi: Hatice Hale Gümüş, Baskent University Faculty of Medicine, Adana Dr Turgut Noyan Teaching and Research Hospital, Department of Medical Microbiology, Dadaloglu District, 2591 Street, No:4/A, 01250, Yuregir, Adana, Turkey e-mail: hhaleag01@hotmail.com 


\section{INTRODUCTION}

Parasitic (amebic) or bacterial (pyogenic) infections are the main causes of liver abscesses which are an important reason for hospitalization in low and middle-income countries. Depending on the etiology, the pathophysiology, diagnostic method and treatment of liver abscesses vary. Pyogenic liver abscesses (PLA) require percutaneous drainage combined with effective antimicrobial therapy, while amebic liver abscesses require only medical treatment. PLA is a polymicrobial infection caused by gram-negative aerobic and anaerobic microorganisms ${ }^{1,2}$.

Gemella morbillorum is a catalase negative, facultative anaerobe, gram-positive cocci located in the microbiome of the upper respiratory, gastrointestinal, and genitourinary tracts. It is unusual for G. morbillorum to be an infectious agent. There are a limited number of Gemella morbillorum-related infections in the literature, and are usually in the form of bacteremia or localized infections (endocarditis, brain abscess, meningitis, arthritis, thrombophlebitis) in humans ${ }^{3}$. To the best of our knowledge, there are only two presented cases of G. morbillorum associated pyogenic liver abscess in the English literature, and we present the first case report in Turkey with imaging, laboratory and clinical findings.

\section{CASE PRESENTATION}

A 57-year-old female patient with no known comorbids except asthma presented in Infectious Diseases Department with complaints of chills, fever, weakness and epigastric pain intermittently for two months. Two months ago, she told to the clinician that she had used an antimicrobial tablet for a week which she could not remember the name, oral vitamin $\mathrm{D}$ and intramuscular combination of betametazon dipropiyonat and betametazon sodium fosfat for her complaints. There were no other features in her medical history and family medical history. On admission, the patient's body temperature was $36.8^{\circ} \mathrm{C}$, her pulse was $98 / \mathrm{min}$, and her blood pressure was $135 / 80 \mathrm{mmHg}$. On physical examination, the patient had no skin lesions or findings of dehydration, but appear pale. The liver and spleen were not palpable, but there was a tenderness in the right upper quadrant of the abdomen. Findings on other systems' examinations were normal.

Laboratory parameters at admission showed neutrophilic leukocytosis, microcytic hypochromic anemia, a mild increase in liver function tests. Erythrocyte sedimentation rate (ESR), C-reactive protein (CRP) and procalcitonin were elevated (Table 1). The patient was hospitalized to investigate origin of infection. Iron sulfate capsule (1x100mg) was prescriped for her anemia. A set of blood culture and urine culture were collected before starting empiric antimicrobial treatment with intravenous piperacillin tazobactam $(3 \times 4.5 \mathrm{gr})$ and metronidazole tablet $(3 \times 500 \mathrm{mg})$. The laboratory tests' results are shown in Table 1. Transabdominal ultrasonography (USG) showed a hypoechoic lesion with irregular borders in the right lobe. Upper abdominal magnetic resonance (MRI) showed a mass lesion with a lobulated contour and budding cysts in the right lobe segment. Additionally, computed tomography (CT) showed perilesional hypodensity (Figure 1).

The patient underwent fine needle aspiration biopsy and percutaneous drainage of the liver lesion. The cytological examination of aspiration fluid showed necrotic material, intensive mixed-type inflammatory cell infiltration, and absence of neoplastic cells. In the stained microscopic examination of the purulent aspiration fluid, dense polymorphonuclear leukocyte (PMNL) and gram-positive cocci were observed. The Vitek 2 System (bioMe'rieux, France) typified the grampositive cocci in the aspiration fluid culture as 
Gemella morbillorum. The bacterium was susceptible to penicillin (MIC value $0.047 \mathrm{mg} / \mathrm{dl}$ ), cefepime, ceftriaxone, vancomycin, clarithromycin, ciprofloxacin and clindamycin according to the European Antimicrobial Susceptibility Testing Committee criteria. A transthoracic echocardiography, which was taken considering possible concomitant endocarditis, showed only mitral insufficiency, no typical finding in favor of vegetation, and there was no reproduction in repeated blood cultures.

The physical status and laboratory parameters on the seventh day of hospitalization are shown in
Table I. She was ready for discharge with anemia treatment and antibiotherapy of oral ciprofloxacin tablet $(2 \times 500 \mathrm{mg})$, metronidazole tablet (3x500 mg).

In the first month control of the patient; the general condition was good, and she had no history of fever or pain. Laboratory parameters are seen in Table 1. The control CT showed that the lesion getting smaller with axial dimensions $46 \times 47 \mathrm{~mm}$ at the abscess site drained in the right lobe (Figure 1). It was decided to continue antibiotic therapy and anemia treatment until the abscess disappeared on the imaging method.

Table I: Results of the laboratory tests.

\begin{tabular}{|c|c|c|c|c|c|}
\hline Test & Day 1-2 & Day 7 & First month control & $\begin{array}{|ll|}\begin{array}{l}\text { Third } \\
\text { control }\end{array} & \text { month } \\
\end{array}$ & Reference Range \& Unit \\
\hline White blood cell & 11.54 & 6.89 & 10.21 & 7.94 & $4500-11000$ cells $/ \mu l$ \\
\hline Neutrophils & 64.53 & 61.45 & 47.63 & 47.11 & $40-72 \%$ \\
\hline Hemoglobin & 10.21 & 9.33 & 11.76 & 14.63 & $12-16 \mathrm{gr} / \mathrm{dl}$ \\
\hline Hematocrit & 30.39 & 29.73 & 36.33 & 44.29 & $35-46 \%$ \\
\hline Erythrocyte & 4.00 & 3.81 & 4.58 & 5.30 & $4-5.20 \times 10^{6} \mathrm{cells} / \mu \mathrm{l}$ \\
\hline Mean corpuscular volume & 76.02 & 77.99 & 79.39 & 83.55 & $80-96 \mathrm{fl}$ \\
\hline $\begin{array}{l}\text { Mean corpuscular } \\
\text { hemoglobin concentration }\end{array}$ & 33.58 & 31.37 & 32.38 & 33.03 & $32-36 \mathrm{gr} / \mathrm{dl}$ \\
\hline $\begin{array}{l}\text { Red blood cells distribution } \\
\text { width }\end{array}$ & 14.10 & 15.34 & 18.94 & 14.89 & $8-18 \%$ \\
\hline Platelet & 356.70 & 321.60 & 360.10 & 164.20 & $150-400 \times 10^{3}$ cells $/ \mu \mathrm{l}$ \\
\hline $\begin{array}{l}\text { Erythrocyte sedimentation } \\
\text { rate }\end{array}$ & 64.00 & 43 & & 3.00 & $0-20 \mathrm{~mm} / \mathrm{saat}$ \\
\hline $\begin{array}{ll}\begin{array}{l}\text { C-reactive } \\
\text { (turbidometric) }\end{array} & \text { protein } \\
\end{array}$ & 168.00 & 87.90 & 29.80 & $<2$ & $<5 \mathrm{mg} / \mathrm{dl}$ \\
\hline Procalcitonin & 0.24 & & & & $<0.12 \mathrm{ng} / \mathrm{ml}$ \\
\hline Glucose & 106 & & & & $70-139 \mathrm{mg} / \mathrm{dl}$ \\
\hline Alanine aminotransferase & 30 & 32 & 14 & 12 & $0-55 \mathrm{U} / \mathrm{L}$ \\
\hline $\begin{array}{l}\text { Aspartate } \\
\text { aminotransferase }\end{array}$ & 21 & 53 & 28 & 24 & $5-34 \mathrm{U} / \mathrm{L}$ \\
\hline Alkaline phosphatase & 177 & 248 & & & $40-150 \mathrm{U} / \mathrm{L}$ \\
\hline Total bilurubin & 0.49 & 0.50 & & & $0.20-1.20 \mathrm{mg} / \mathrm{dl}$ \\
\hline Anti-HCV & Negative & & & & \\
\hline $\mathrm{HBsAg}$ & Negative & & & & \\
\hline Anti-HIV & Negative & & & & \\
\hline Urine culture & Negative & & & & \\
\hline Blood culture & Negative & & & & \\
\hline Aspiration fluid culture & & \begin{tabular}{|l|} 
Gemella \\
morbillorum
\end{tabular} & & & \\
\hline Tuberculosis culture & & Negative & & & \\
\hline $\begin{array}{l}\text { Brucella aglutination (Rose } \\
\text { Bengal) }\end{array}$ & Negative & & & & \\
\hline $\begin{array}{l}\text { Brucella aglutination (with } \\
\text { Coombs antiserum) }\end{array}$ & Negative & & & & \\
\hline $\begin{array}{l}\text { Brucella tube aglutination } \\
\text { (Wright test) }\end{array}$ & Negative & & & & \\
\hline $\begin{array}{l}\text { Hydatid } \\
\text { hemagglutination test }\end{array}$ & Negative & & & & \\
\hline
\end{tabular}


On the third month follow-up MRI of the patient, it was observed that the abscess formation had completely disappeared (Figure 1). The patient recovered with laboratory and imaging findings back to normal.

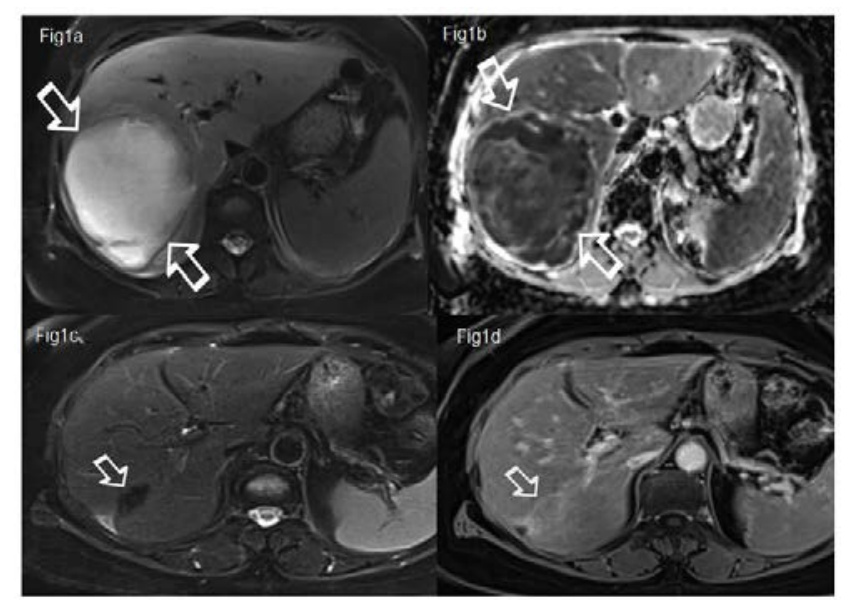

Figure 1. Patient's radiological imaging results. Prepercutaneous drainage of the lesion; a) MRI showed hyperintense content on T2 weighted MRI and b) restricted diffusion related to viscous content was seen on clear diffusion coefficient (ADC) map. c) Three months later after treatment, control T2 and d) T1 weighted enhanced MRI shows no residual abscess.

\section{DISCUSSION}

It is unusual for G. morbillorum not only to be an infectious agent in humans, but also a causative agent of a liver abscess.

Up to $55 \%$ of patients with PLA have no clear risk factors ${ }^{1}$. In the literature, two ${ }^{4,5}$ of the previously reported cases had no concomitant disease, but two $^{3,6}$ had diabetes, and one ${ }^{7}$ had a duodenal ulcer. On the other hand, in this patient, there was no comorbidity other than asthma, but it was thought that immune system suppression due to a single dose of corticosteroids administered two months ago was in question. This case underlines the fact that pathogenic potential of G. morbillorum cannot be underestimated.
The right hepatic lobe was reported to be the most common anatomical location in all reported cases similar to this case ${ }^{3-7}$.

As in this case report, the most common presenting symptoms and signs of PLA were fever, weakness and abdominal pain in reported cases $^{3-7}$. Some nonspecific symptoms such as swelling ${ }^{3}$, runny nose ${ }^{7}$ were also previously reported. Since the symptoms are subtle and not specific, suspicion is the cornerstone of early diagnosis and treatment.

Besides clinical history, elevation of ESR and CRP, neutrophilic leukocytosis and toxic granulation in peripheral smear were interpreted in favor of infection. The imaging methods suggested that the mass is a liver abscess or neoplasm. Although USG, CT and MRI imaging methods show high sensitivity in the diagnosis of liver abscesses, cytological and microbiological examination of fine needle aspiration biopsy material is required for the distinction of abscess/neoplastic mass ${ }^{1}$. As a matter of fact, cytological examination of aspiration fluid revealed intensive mixed-type inflammatory cell infiltration and gram-positive cocci, not neoplastic cells.

Current recommendations for treatment for PLA are percutaneous or surgical drainage aided by imagery and antimicrobial therapy ${ }^{1}$. Liver abscesses smaller than $3 \mathrm{~cm}$ can be treated medically. While surgery is preferred in complicated cases requiring multiple abscesses or repeated intervention, percutaneous drainage (repeated if necessary) is used as it is a less invasive method. Antimicrobial guidelines recommend empiric therapy targeting both amebic and pyogenic causes of liver abcess ${ }^{1}$. It has been reported in the literature that all PLA cases due to G. morbillorum completely recovered with percutaneous drainage and antibiotic treatment similar to this case $\mathrm{e}^{3-7}$.

In conclusion, we present a rare case of PLA due to G. morbillorum in an immunocompetent 
patient supporting the pathological potential of this microorganism. Since the symptoms are subtle and not specific, suspicion is the cornerstone of early diagnosis and treatment. The patients of G. morbillorum liver abscess require to be treated with appropriate antibiotics and percutaneous drainage. Culture of aspirated abscess contents should always be performed to ensure targeted antimicrobial therapy.

Informed Voluntary Consent Form: Informed written consent was obtained from the patient for publication of this report and any accompanying images.

Ethical approval: This case report has been evaluated and approved by Ethics Committee for Non-Interventional Studies of Baskent University.

Conflict of Interest: The authors declared no conflict of interest.

Financial Disclosure: No financial disclosure was declared by the authors.

\section{REFERENCES}

1. Khim G, Em S, Mo S, et al. Liver abscess: diagnostic and management issues found in the low setting. $\mathrm{Br}$ Med Bull. 2019; 132: 45-52.

2. Serraino C, Elia C, Bracco C, et al. Characteristics and management of pyogenic liver abscess: $A$ European experience. Medicine (Baltimore). 2018; 7: e0628.

3. Hsu CY, Su YC, Wang TL, et al. Gemella morbillorum liver abscess. Scand J Infect Dis. 2007; 39: 637-8.

4. Borro P, Sumberaz O, Testino G. Pyogenic liver abcess caused by Gemella morbillorum. Colomb Med (Cali). 2014; 45: 81-4.

5. Park IW, Park S, Park J, et al. Liver Abscess due to Gemella morbillorum in a Healthy Woman. Infect Chemother. 2011; 43: 363-6.

6. Nam HJ, Yoon SJ, John BM, et al. Liver abscess caused by Gemella morbillorum. Korean J Gastroenterol. 2005; 46: 56-9.

7. Garcia PJ, Hernandez DVE, Rodriguez MJ, et al. Liver abscess: a rare manifestation of Gemella morbillorum infection. Med Clin (Barc). 2002; 118: 239. (In Spanish). 